http://jurnal.stmikroyal.ac.id/index.php/jurdimas

\title{
PELATIHAN PENGOLAHAN NILAI SISWA UNTUK PEGAWAI DAN GURU PADA SMP NEGERI 5 KISARAN
}

\author{
Jeperson Hutahaean ${ }^{1 *}$, Cecep Maulana ${ }^{1}$, Ramadhani $^{1}$, Nuriadi Manurung ${ }^{1}$, \\ Zulfi Azhar ${ }^{1}$, Nofriadi $^{1}$ \\ ${ }^{1}$ Program Studi Sistem Informasi STMIK Royal Kisaran \\ Email : jepersonhutahaean@ royal.ac.id,
}

\begin{abstract}
Activities devotion to the community is in the form of training table for the processing of student value for employees and teachers SMP Negeri 5 Kisaran. It aims to provide knowledge, skills, which are expected to result in changes in knowledge, skills and from employees and teachers so that the process of processing student values can run smoothly and easily. Target audiences in community service activities are employees and teachers of SMP Negeri 5 Kisaran. The training activities are presented with lecture, demonstration and question and answer methods. The availability of adequate lecturers, enthusiasm of the participants, and the support of the principal is a support for the implementation of this PKM activity. The obstacles faced is the ability of participants to use this application is still low. Benefits derived from this activity include participants can know about the significance of the use of Micrososft Excel primarily using the table on processing the value of suswa always used by teachers in schools in entering student value and application of basic formula in accelerate the processing of other data.
\end{abstract}

Keywords: Teachers, Microsoft Excel, Student Values, Employees, Tables

\begin{abstract}
Abstrak: Kegiatan pengabdian kepada masyarakat ini yaitu berupa pelatihan pembuatan tabel untuk pengolahan nilai siswa bagi pegawai dan guru-guru SMP Negeri 5 Kisaran. Hal ini bertujuan untuk memberikan pengetahuan, keterampilan, yang diharapkan dapat menghasilkan perubahan pengetahuan, keterampilan dan dari para pegawai dan guru sehingga proses pengolahan nilai siswa dapat berjalan dengna lancar dan mudah. Khalayak sasaran dalam kegiatan pengabdian kepada masyarakat ini adalah pegawai dan guru-guru SMP Negeri 5 Kisaran . Kegiatan pelatihan ini disajikan dengan metodeceramah, demonstrasi dan tanya jawab. Ketersediaan dosen yang memadai, antusiasme peserta, dan dukungan kepala sekolah merupakan pendukung terlaksananya kegiatan PKM ini.Adapun kendala yang dihadapi adalah kemampuan peserta menggunakan porgram aplikasi ini masih rendah.Manfaat yang diperoleh dari kegiatan ini antara lain peserta dapat mengetahui tentang arti pentingnya penggunaan Micrososft Excel terutama menggunakan tabel pada pengolahan nilai suswa yang selalu digunakan oleh para guru-guru di sekolah dalam memasukkan nilai siswa dan aplikasi formula dasar dalam mempercepat pengolahan data lainnya.
\end{abstract}

Kata Kunci: Guru,Microsoft Excel, Nilai siswa, Pegawai, Tabel 
http://jurnal.stmikroyal.ac.id/index.php/jurdimas

\section{PENDAHULUAN}

Pengabdian kepada masyarakat merupakan pelaksanaan pengamalan ilmu pengetahuan, teknologi dan seni budaya langsung pada masyarakat secara kelembagaan melalui metodologi ilmiah sebagai penyebaran Tri Dharma Perguruan Tinggi serta tanggung jawab yang luhur dalam usaha mengembangkan kemampuan masyarakat, sehingga dapat mempercepat laju pertumbuhan tercapainya tujuan pembangunan nasional.

Dalam kehidupan masyarakat modern dewasa ini sadar maupun tidak sadar kita selalu menggunakan teknologi komputer sebagai sarana dalam mendukung aktifitas maupun tugas-tugas yang dilakukan. Dengan adanya pelatihan pengolahan nilai ini pegawai dan guruguru lebih optimal dan lebih mudah saat mengolah nilai, oleh karena itu efektifitas dan efisiensi bisa dicapai yang akhirnya produktifitas menjadi lebih tinggi dalam menyelesaikan berbagai jenis pekerjaan yang dilakukan

Peningkatan peran dan kualitas guru bisa dilakukan dengan berbagai cara diantaranya: (1) guru tidak hanya menguasai bidang studinya, tetapi menguasai iptek yang memadai dan mengintegrasikannya ke dalam bidang studi yang diajarkan, (2) guru perlu menanamkan nilai budaya masyarakat industri kepada peserta didik, (3) membantu murid dalam mencari sumber informasi, (4) penyesuaian jenjang pendidikan dengan kebutuhan dan kemajuan iptek bagi guru dan lain sebagainya. Seorang guru harus menguasai bahan ajar, memilih metode dan media dengan tepat, mampu mengelola program PBM, mampu melaksanakan bimbingan dan penyuluhan dengan baik dan memahami hasil-hasil penelitian. Guru yang profesional akan mampu menciptakan suasana belajar yang efektif. Salah satunya adalah dimana seorang guru harus mampu mengolah data nilai dengan menggunakan komputer Microsoft Excel.

Khalayak sasaran pada pengabdian masyarakat yang dilaksanakan adalah pada pegawai dan guru-guru SMP Negeri 5 Kisaran.Diharapkan setelah kegiatan ini para pegawai dan guru-guru mampu mengolah nilai.

\section{METODE}

Ada beberapa materi dan metode yang digunakan dalam pengabdian masyarakat ini, yaitu:
1.1 Materi Pengabdian Kepada
Masyarakat
Pelatihan Pembuatan tabel dan penggunaan rumus dasar Microsoft Excel.

\subsection{Metode pengajaran yang dilakukan \\ Metode pengajaran yang dilakukan} adalah sebagai berikut :

1. Metode Transfer ilmu

Metode ini dilakukan dengan cara menularkan ilmu sekaligus memberikan pelatihan mengenai pembuatan tabel bagi guru-guru dan pegawai di SMP Negeri 5 Kisaran.

2. Metode Penyampaian

Metode penyampaian yang dilaksanakan dalam program ini adalah pelatihandan prakteklangsung. Peserta mempraktekkan secara langsung cara membuat tabel dan rumus (formula) dasar pada Microsoft Excel sehingga lebih mudah dipahami. Dengan demikian tujuan yang diharapkan dalam pelaksanaan program ini dapat dicapai. Kegiatan ini dilaksanakan pada tanggal 19dan 20 Desember 2017 bertempat di SMP Negeri Kisaran, Kabupaten Asahan Sumatera Utara. Susunan kegiatan dan jadwal kegiatan meliputi tahap pengenalan Microsoft Office, Microsoft Excel, sampai ke tahap pembuatan tabel dan dilanjutkan dengan tanya jawab. Kegiatantanya jawab dilakukan bersamaan dengan 
http://jurnal.stmikroyal.ac.id/index.php/jurdimas

penyajian materi.Para peserta dapat langsung berdiskusi dengan para pemateri secara langsung untuk lebih memahami materi dan sharing pengalaman terkait dengan masalah yang tengah dibahas dengan materi bersangkutan.

\section{PEMBAHASAN}

Kegiatan pengabdian masyarakat yang telah direncanakanoleh dosen STMIK Royal Kisaran pada SMP Negeri 5 Kisaran dengan tema Pengolahan Nilai Siswa Untuk Pegawai dan Guru Pada SMP Negeri 5 Kisaran dan telah direalisasikan tanggal 19 dan 20 Desember 2017. Kegiatan pengabdian masyarakat dilaksanakan di ruang Kantor SMP Negeri 5 Kisaran.Untuk kelancaran pelatihan maka pihak sekolah meminta masing-masing peserta membawa notebook.

Bentuk pelatihan yang diberikan meliputi materi kajian dasar dan materi kajian yang dijabarkan dalam langkahlangkah kerja. Pembahasan materi tersebut sesuai dengan materi yang telah dipersiapkan.Pembahasan menyangkut pengertian sampai ke manfaat aplikasi penggunaan tabel untuk pengolahan nilai siswa. Kemudian pembahasan dilanjutkan dengan pelatihan penggunaan dasar tabel. Dari hasil observasi tim peneliti di lapangan, peserta cukup antusias dengan adanya pelatihan hal ini ditandai dengan rata-rata peserta membawa notebook mereka masing-masing untuk mengikuti setiap arahan yang diberikan instruktur dalam pelatihan ini. Beberapa guru ada yang sudah cukup mahir dalam menggunakan Microsoft Excel untuk pembuatan tabel.

Hasil dari kegiatan pengabdian masyarakat yang telah dilakukan oleh Tim dosen pengabdian masyarakat sudah sesuai dengan yang diharapakan.Peserta sudah mengerti dan memahami tentang pelatihan kegiatan ini. Selain itu peserta memahami keuntungan menggunakan aplikasi Microsoft Excel ini, pengaruh penggunaannya dalam penggunaan tabel yang dapat digunakan dalam pengolahan nilai siswa.

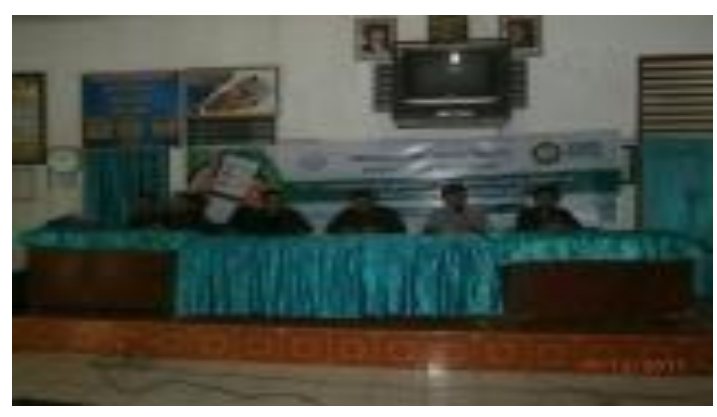

Gambar 1 Pelatihan Dosen STMIK Royal Kisaran di SMP Negeri 5 Kisaran

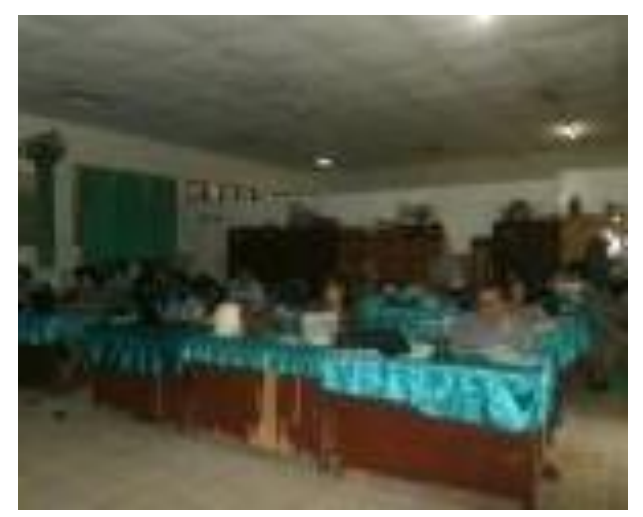

Gambar 2 Para Pegawai dan Guru Sedang Melakukan Pembuatan Tabel Pengolahan Nilai

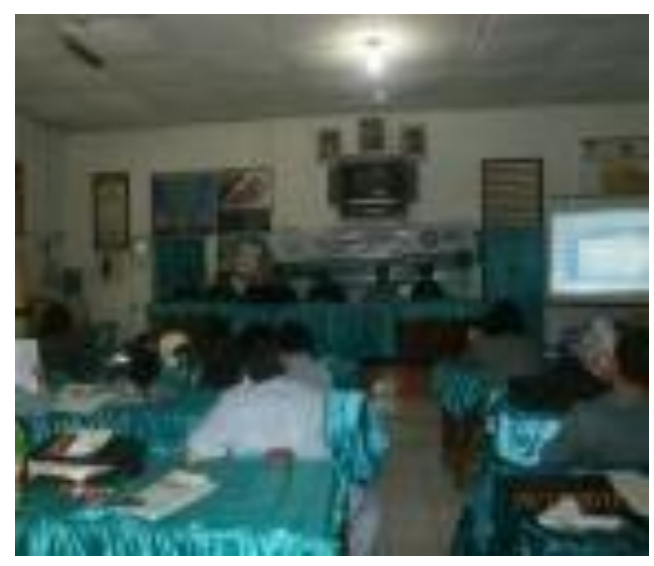

Gambar 3 Para Pegawai dan Guru Mendengarkan Cara Penggunaan Aplikasi Tabel Pengolahan Nilai 
http://jurnal.stmikroyal.ac.id/index.php/jurdimas

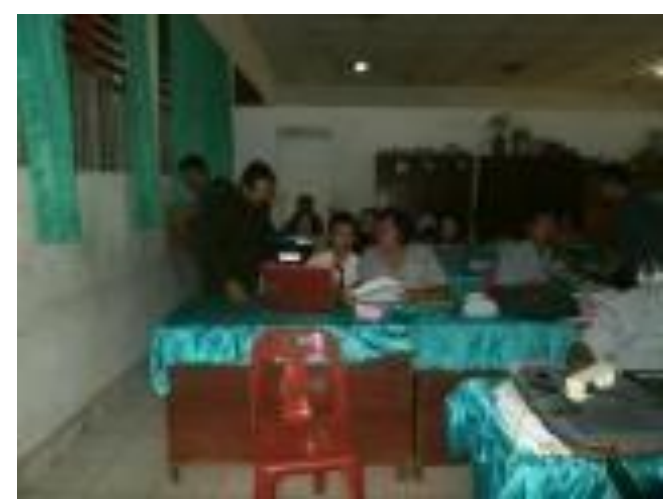

Gambar 4 Para Pegawai dan Guru Sedang Melakukan Pembuatan Tabel Pengolahan Nilai Dengan Arahan Dari Dosen STMIK Royal Kisaran

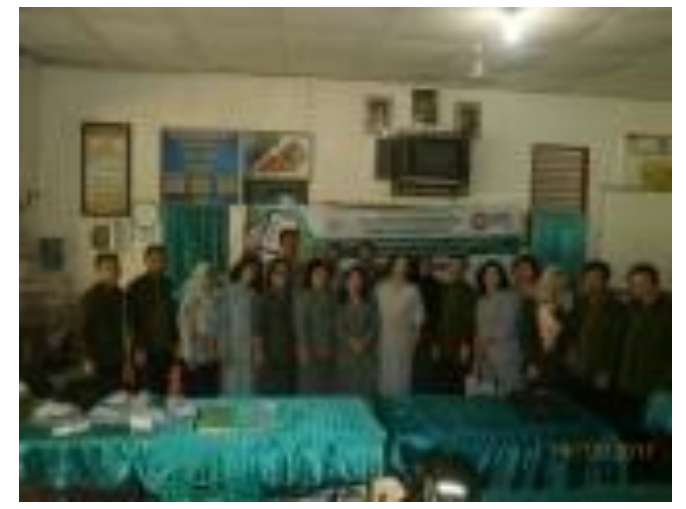

Gambar 5 Para Pegawai dan Guru Dan Dosen STMIK Royal Kisaran Berfoto Bersama

\section{SIMPULAN}

Kegiatan Pengabdian kepada masyarakat tentang pelatihan pengolahan nilai berjalan dengan baik dan lancar sesuai dengan rencana yang telah disusun meskipun belum semua peserta menguasai materi yang telah disampaikan. Kegiatan ini mendapat sambutan yang sangat baik terbukti dengan keaktifan para peserta mengikuti semua tahap dan tidak meninggalkan tempat sampai waktu pelatihan berakhir.

\section{DAFTAR PUSTAKA}

Krisianto, Andy , (2015), Jago Fungsi Dan Rumus Excel, Elexmedia Komputindo, Yogyakarta

Yudhy Wicaksono dan Solusi Kantor, (2015), Cara Cepat Menyelesaikan Pekerjaan Dengan Excel, Elexmedia Komputindo, Yogyakarta

Enterprise, Jubile (2015), Microsoft Office 2013 Untuk Pemula, Elexmedia Komputindo, Yogyakarta

Musliadi (2014), Secret Fungsi dan Formula Pada Excel 2013, Andi, Yogyakarta

Edy Winarno, Ali Zaki dan Smitdev Community (2015), Dasbor dan Report di Excel, Elexmedia Komputindo, Yogyakarta

Mangkulo Alexander, Hengky (2010), Microsof Excel 2010 Untuk Pemula, Elexmedia Komputindo, Yogyakarta 